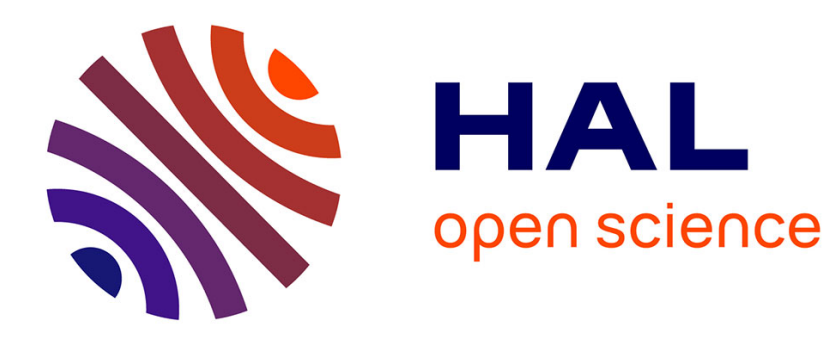

\title{
When the Boundaries are Blurred
}

Halleh Ghorashi

\section{To cite this version:}

Halleh Ghorashi. When the Boundaries are Blurred. European Journal of Women's Studies, 2005, 12

(3), pp.363-375. 10.1177/1350506805054275 . hal-00571251

\section{HAL Id: hal-00571251 \\ https://hal.science/hal-00571251}

Submitted on 1 Mar 2011

HAL is a multi-disciplinary open access archive for the deposit and dissemination of scientific research documents, whether they are published or not. The documents may come from teaching and research institutions in France or abroad, or from public or private research centers.
L'archive ouverte pluridisciplinaire HAL, est destinée au dépôt et à la diffusion de documents scientifiques de niveau recherche, publiés ou non, émanant des établissements d'enseignement et de recherche français ou étrangers, des laboratoires publics ou privés. 


\title{
Open Forum
}

\section{When the Boundaries are Blurred}

\section{The Significance of Feminist Methods in Research}

\author{
Halleh Ghorashi
}

DE VRIJE UNIVERSITEIT

\begin{abstract}
This article focuses on the ways that the author's somewhat inbetween position as both an outsider/researcher and an insider/ex-political Iranian activist now in exile has contributed to the process of research on Iranian women exiles in the Netherlands and the United States. Feminist attention on life stories as a method, and feminist anthropologists' attention to particularity, involvement and reflexivity give the author the space, and inspire her, to explore the issue of positioning. This makes it possible for her to engage with the issues of home, identity and belonging, not only as a scholar but also as a woman in exile. In this way, the reflexivity resulting from this involvement enables her to reevaluate her own identity, sense of belonging, and life in exile, next to rethinking these essential themes within the social sciences on the theoretical level. The blurred boundary of the self and the other in her research has its moments of complication, but in the end, these complicated moments seem to be not only necessary but rewarding, in many ways.
\end{abstract}

KEY WORDS belonging $\bullet$ exile $\bullet$ feminist anthropology $\bullet$ home $\bullet$ identity $\bullet$ Iranian women $\bullet$ life stories $\bullet$ positioning

I was 26 years old when I came to the Netherlands in 1988, as an exile from Iran. Although young in years, I felt as if I had undergone an intensive course in life. Often I felt as if my shoulders could not carry my memories: both the beautiful and the horrific. At the age of 17, I 
participated in the Iranian Revolution of 1979 as a leftist political activist. From 1981, I experienced years of suppression, living day by day in fear of being killed or arrested. Once in exile, I felt as if I had entered an empty space, where neither present nor future mattered; the only thing that mattered was the past. How could I deal with the memories of so many high ideals and so many disappointments? I entered a domain in which feelings of displacement and in-betweenness became part of daily life. Questions of identity and home started to have a central place in my mind and in my life.

My academic education in the Netherlands as an anthropologist provided me with some tools to approach this encounter with exile. Reading new theories about identity, home and exile attracted my interest but left me confused. The emphasis on the dynamic and changing aspects of identity and constructed meanings of home and culture seemed appealing, but also left me with many unanswered questions. Why were exiles like me unable to feel at home in their new countries? Why were exilic experiences so strongly coloured by the past and nostalgia for a lost home? If identities and the meanings of home are so flexible, as often assumed, why are exilic subjects not able to come to terms with their position in life based on their achievements in their new countries? I remember reading Said's Culture and Imperialism and coming across a passage from Hugo of St Victor:

The person who finds his homeland sweet is still a tender beginner; he to whom every soil is as his native one is already strong; but he is perfect to whom the entire world is as a foreign place. The tender soul has fixed his love on one spot in the world; the strong person has extended his love to all places; the perfect man has extinguished his. (Said, 1994: 407)

Hugo's vision provided me with a conceptual framework within which to position myself. I started to question my exclusive love for my homeland, when I appropriated Marxist ideas while active in a leftist organization. In those years, I distanced myself from the idea of a national homeland and began to believe in the Marxist ideology that saw the world as a homeland'. Later I completely lost the illusion of a sweet homeland when political violence made me a refugee in my own country. Thus, my first experience of being a cosmopolitan citizen was formed partly through my Marxist belief but mainly by the harsh experience of becoming an internal exile. That marks the time when I can say that I passed the stage of 'a tender beginner'. Once in exile in the Netherlands, I realized the reverse of this process. I began to develop strong nostalgic feelings towards Iran. I started to idealize Iran as my homeland: the only country where I could truly belong. As the years passed, this imaginary Iran became stronger in my mind, which led to feelings of displacement and emptiness in the present. The painful consequence was that I was banned from the only 
country that I considered as my homeland. A sense of emptiness shadowed my life in the Netherlands, a life that in no way was an isolated one, because I was quite successful there. However, this feeling of living in-between spaces (there and here) and time (past and present) created the unsatisfactory situation of longing for my sweet homeland. So I retreated to the stage of 'a tender beginner'.

In 1995, when I began a project about Iranian women exiles in the Netherlands and the US, I wanted to know what happened to our generation of women who participated in the Iranian Revolution and now live in exile. What happens to cosmopolitan ${ }^{1}$ minds like ours when we enter exile? Do we all return to the nostalgic, nationalistic thoughts of 'a tender beginner', or are some of us able to become the 'perfect' one: 'to whom the entire world is as a foreign place'? But before I consider the condition of these women in exile, it is important to contextualize their revolutionary background in Iran.

\section{A REVOLUTION THAT CHANGED LIVES}

In my research, I listened to the stories of women leftist activists who were forced to leave Iran because of their political activities during the Iranian Revolution of 1979. Women's involvement in the Iranian Revolution of 1979 took place at many different levels. Their most intense participation was during the two years following the overthrow of the Pahlavi regime (1926-79). This was a period of political freedom resulting from a power vacuum. A number of political groups came into existence, and were then permitted by law. These groups advanced a wide range of ideologies, including various forms of Marxism, Islamism, liberalism and women's rights. Both the extent of the freedom enjoyed during these years and the opportunity for political involvement gave Iranian women the chance to acquire political identities in an extensive manner for the first time.

The 'spring of freedom' ${ }^{2}$ did not last long. Confrontations had been growing between secular/leftist political parties and the Islamists in power from the very beginning of the revolution. Those confrontations took a turn for the worse on 18 June 1981. From that date on, the streets of Tehran and other Iranian cities began to witness terrible violence. Islamists began institutionalizing their absolute power. All other political groups were declared illegal, and the majority of their followers were arrested, tortured, or killed. Those who had the chance left the country and became exiles. A new start in a new country went hand in hand with the memories of a lost home and an insecure future.

The women who were part of this research had participated in the Iranian Revolution of 1979 within leftist organizations. They had left Iran when the years of suppression started after 1981. My fieldwork, which 
took eight months in each country, was concentrated in Amsterdam in 1996 and Los Angeles in 1997. During this time I listened to the life stories of 20 women in each country. I also did several months of participant observation within the local Iranian communities to grasp the dynamics that existed in both contexts. The main focus of the comparative research was to understand the impact of the new countries on the ways that the women told stories of the past, present and future.

The most striking outcome of this research was that these leftist political activists, with their relatively common pasts, positioned themselves completely differently in their new countries. The women in the Netherlands felt like strangers and were afraid of the future. 'What is going to become of us here? We will never find our place here, but is there any place for us left in Iran?' Their sense of non-belonging in the Netherlands does not mean that they were not part of the society. The contrary is the case: they speak the language and are active participants within society. But why did they feel like strangers there, and why were they afraid of the future? The women in Los Angeles have similarly contributed as active participants in their new society. The big difference was that they felt that they belonged in their new country. They felt at home in Los Angeles and were not afraid of the future. 'If I have been able to gain so much within the 10 years I have lived here, then I will achieve even more in 20 years. Why should I be afraid of the future then?' To explore the differences between the two countries I have elaborated on a combination of factors that involve levels of experience, structure and discourse. Unfortunately, the methodological focus of this article does not leave any space to explore these factors (for more on this, see Ghorashi, 2003a, 2003b).

\section{SADNESS AND PASSION: BOTH A RESEARCHER AND A POLITICAL ACTIVIST}

The question that kept me busy from the first year of this research project was how to combine my personal experiences as a leftist activist in exile with the research I was planning to conduct. I was enormously inspired by the works of feminist anthropologists such as Lila Abu-Lughod (1991) and Ruth Behar (1996). In their works these scholars give special attention to creative as well as critical writing (Behar and Gordon, 1995: 7). Stressing the particularity of experiences against simple generalizations leaves space for 'writing against culture', which subverts the process of othering within anthropology (Abu-Lughod, 1993: 13). These scholars draw attention to the construction of research material that was to a large extent shaped and influenced by the personal background and experiences of the researcher. From the beginning I have intended to present my writing in a way that not only gives room to emotions, but also opens a window to 
my personal background as both an activist and researcher. In addition, I wanted my work to touch people's hearts and minds. The feminist anthropological choice in reflexive and experimental writing provided me with a perfect framework.

To collect material for this study, I used a range of field methods and techniques: participant observation, life stories and short interviews on specific topics. By giving the women I interviewed the space to narrate their lives, the life story method (Berger et al., 1991) was essential to the research. Historical dimension gives space to the experiences and the choices of the women in their new countries, and it also highlights recollections of the past and their impact on the present. The life story method gave space to an interaction between past activism, present experiences of exile and future expectations. What these women went through during the political changes in Iran, the reasons for their flight and their problems in the new countries are often very painful subjects that are usually difficult to talk about in an interview. Since these are situations that the women would rather forget, survey methods that merely provide a dispersed picture of such experiences would not succeed in giving the women the opportunity to express their feelings within a dialogue (Anderson and Jack, 1991). The role of the researcher within this method is mostly to listen to what those interviewed have to say. A researcher should raise some orienting questions, but the character of the interview should be such that the narrator feels free to express her complex and conflicting experiences.

\section{MIRRORING EFFECT OF LIFE STORIES}

The intensity of the narratives of the women I interviewed affected me enormously throughout the research period. During my fieldwork in the Netherlands, I discovered that I would travel back to the past because of the character of some of the interviews. I experienced nightmares on several occasions, but did not really ask myself why. I had in fact anticipated this, as I had expected some of the interviews to affect me deeply. However, I later realized that I did not have nightmares after all of the interviews. I read the transcripts of the interviews again, and was amazed with the result. I noticed that some of the interviews created an atmosphere in which I travelled back in time. This was a result of the vocabulary used by the women. They were using the revolutionary words of the past, a vocabulary that for all of us belonged to the past. Those old revolutionary terms unconsciously carried me back to that past. To clarify this point, I give an example of the vocabulary of those years. I also explain the context because it was not just the words but the context that had such an impact on me. The word that had the most impact on me was dareiha, 
which means 'the valley ones'. When one of the women used it, we both became very emotional and our eyes filled with tears. She said:

Another strong propaganda at that time was that between imperialism and communism there is a kind of valley that should be filled with our blood. We are the ones who should fill that valley with our flesh and blood; we are the valley ones. Then you do not think of being able to see communism itself, you think of just sacrificing to fill the valley as a bridge for others. Because I was the valley one, I could only think of the ways to develop my defensive and revolutionary methods, instead of thinking about having children or not.

Other words that caused me to travel back in time were the names of different sorts of machine guns: Kalashnikov and J-3; ghahrze enghelabi: revolutionary violence; khalq: people; and falanj: dogmatic. I found it amazing that I had not thought of those words for many years and yet they were a very important part of my life for at least two years. During the revolution, we were taught in high school how to use machine guns. I remember that I found it fascinating, and felt that I was already a partisan by taking part in those classes. These words became symbols of the political passion of those years. A nostalgic passion comes back every time those words are mentioned. In this way, revolutionary words became mediators between the past and the present and showed how the past remained an essential part of the present. Expressions were drawn from different periods, and raised deeply embedded emotions. The revival of those words created in me the feeling of being completely transferred to another time, as if I had lived another life. Through those words I relived the events of those years in my dreams as if they were real. For example, in one dream I was chased by Islamic police and was running for my life when I ended up in a dead-end street and woke up. Those events seemed so far away, but still much closer than I expected. For many weeks after conducting these interviews I felt completely exhausted. It was much later that I learned the reason for this exhaustion.

After my flight to the Netherlands, terrible headaches became a part of my life. Sometimes I had to deal with them four days a week. My doctor called it the disease of the modern era and advised me to take painkillers, so I did. After conducting my research in the Netherlands, or maybe it was during the time of the research, I realized that my headaches had become less frequent. It was a great feeling. I could also think about the past more easily and I felt more relieved. Could it be that this research had become my therapy to deal with my memories? I realized that it was. It was not so much the research itself that helped as the discovery that I was and am not alone with my pain and that there are others who went through similarly tough experiences and who are also struggling towards a rather uncertain future. We are people with lost homes and misplaced ideals, people who 
experienced both the nearness of death and the highest moments of joy in life, and people who learned to survive. It feels like a miracle to know that people can talk about lost ideals and hopes, and be surrounded by emotions. It is amazing to talk to others without words, using just the movements of our bodies, the tears in our eyes, and the coldness of our hands. These moments of intense emotions gave me strength to deal with the difficulties of my research and to deal with my own past as it surged to the forefront. Many of the women I interviewed told me that my research affected them deeply by giving them the opportunity to talk about their experiences or by feeling closeness and understanding when they could not find words. Some Iranian men read my articles and told me how deeply they felt a strong common spirit with those who shared the experience of the revolution and exile. This made my work more than scholarship. It made it about sharing stories, matching experiences, and helping each other lift the dominant shadow of the past as much as possible. Being inspired by feminists in general with their attention to life stories as a method, and feminist anthropologists for their attention on particularity, involvement and reflexivity, my work became more about touching hearts than minds, and about changing lives rather than observing them.

\section{INTERSECTION OF THE PRESENT AND THE FUTURE}

When I began this research I assumed that I would be touched by the stories of other Iranian women about their past experiences, but I could not imagine that this research would change my view on life in exile and the future so drastically. The life stories showed me that I was not only escaping from the past but also from the present. In spite of my hard work in learning the Dutch language and finishing my MA in a rather short time, I realized that I was not happy; I was escaping from reality by working like crazy. My feelings of not belonging, of emptiness, became obvious when I was transcribing the interviews of the women in the Netherlands related to the future.

When I first transcribed the women's voices, and listened to the uncertainties of their lives, I had to cry. Realizing how bleak they felt reminded me of my own feelings of uncertainty about the future and the pain of a lost home. It was a rather emotional scene behind the computer, typing and crying. Although I am not at all a poet in any way, I came up with the following, which captures how I felt at that time:

It feels so cold inside,

I feel a loss,

The loss of warm eyes,

Eyes I knew from my childhood, 


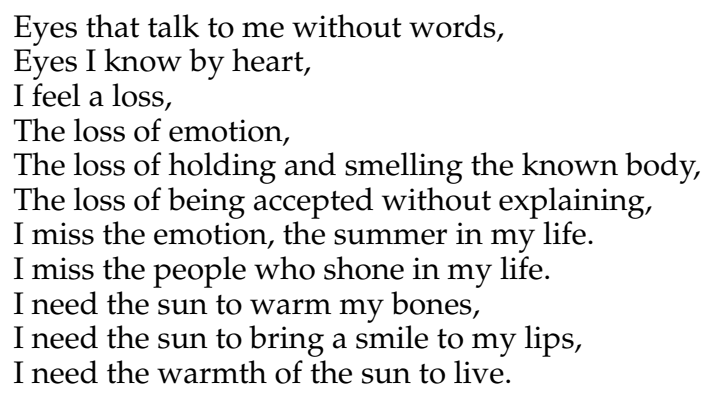

The logic, the winter, is new to me,

But I will die without the sun. (Ghorashi, 1998: 25-6)

This poem expresses the emptiness of my life in exile at that moment. But it is more than that. Contrasting warmth, sun and emotion to cold, winter and logic shows the way I glorified the past that was different from the present. In this way my sense of belonging was related to a selected and imaginary past that contained all the things I was missing in the Netherlands. The poem tells us about the exilic experiences of the writer with strong nostalgic feelings towards the past. The sense of being othered, of not belonging in her new country, and of the insecurity about the future fuelled my creation of a past that gave me hope to stay alive. In this sense my exilic experience was similar to that of the women I interviewed in the Netherlands. This exiled feeling changed during my nine-month stay in California for my fieldwork. The following excerpt from my fieldwork notes in Los Angeles records my feelings.

For many Iranians who were brought up during the time of the Shah, 'Irangeles' feels more like Iran than the Islamic Iran after the revolution. I felt more at home in Los Angeles in many ways; I could relive so many of the similar images of my childhood that I had lost already when I was in Iran. An example:

One of the sweetest memories I have from my childhood is our trip to my aunt's villa in northern Iran in summers. I loved the green, the sea, and the play with the children there. We went there with the whole family and many children. We woke up early in the morning with birds singing, rushed to the sea, and stayed there the whole day. We had the choice either to go to the sea or to the swimming pool. It was a marvellous time. We went there with our bicycles and the whole day was full of joy, playing, swimming, quarrelling, running, and eating. During the night, another picture that I never forget is the smell of barbecue in the garden and several tables settled for adults to play cards. Almost all of our parents played cards deep into the night. We ate, played, and at some point just fainted from exhaustion. My nights mostly ended with the sound of crickets. The morning started with birds and the nights ended with crickets. Of those memories, the sounds stayed part of my life for a long time. 
After the revolution, I did not hear those sounds any more. We went to northern Iran every summer but the scene was completely different. The city of my memories had changed to a city full of Islamic police. That city which was considered as a base for wealthy people became the centre of hatred for revolutionaries. We were not allowed to swim, and having fun became a sin. At some point they said that biking was forbidden for women. I could not believe it and just took my bicycle as usual and headed towards the sea. An Islamist policeman who was hidden behind the trees jumped out and pointed his gun at me. I was totally shocked and just stepped off the bike and went with him to the police office. I was afraid of getting into trouble because of my political background, and for such an unfortunate reason for arrest as riding a bicycle. So I stayed as polite as I could, they called my father, and he guaranteed that I would not ride a bike any more. Another time we were barbecuing in our garden. The garden was surrounded with trees, so my aunt did not wear a scarf, hoping that nobody would see her. At some point, Islamic police attacked the house and wanted to talk to 'the man of the house'. So my father came and they were very rude to him and told him that if he could not control his women they would do it for him. My father felt insulted, and our barbecue and the rest of the week were spoiled. I remember that after that incident we did not have barbecues outside and preferred to stay inside the house with the curtains closed. These were the last pictures of the beautiful city of my memories before I left Iran.

Strangely enough, I felt at home within a month of my arrival in America. The lost home that was neither Iran nor the Netherlands took on another dimension when I came to California. One evening I was invited to a party at the house of a distant relative. Most of my cousins were there too. When I entered the house I was shocked by what I saw. The decoration of the house, tables ready for playing cards, the smell of barbecue and the big plate of fruit hit me immediately. It was such a familiar scene. My grownup playmates and I stayed inside and talked. I heard the sounds again. There were no birds or crickets outside, but I clearly heard them singing. I realized that the feeling of home has little to do with your country of origin, but very much to do with the place you can revive your memories. I was not in Iran or northern Iran recapturing my memories; I was in Los Angeles. And there I felt at home. It was a displaced home, which fitted into my constructed memories. A combination of different factors made Los Angeles home when the 'real home', Iran, lost its meaning as home. Nevertheless, this feeling of home for a refugee is fleeting and momentary. It is something that one searches for, but it does not last long. Home and homelessness become feelings of mere moments for migrants, moments one cherishes and dislikes at the same time. Feeling closeness but fearing betrayal, the question that keeps you busy becomes: will this moment betray me? 
Unfortunately, that moment betrayed me. But it took a while before it happened. During my fieldwork in California I was happy with my research, the friends I found, the Iranian parties, and the ceremonies that I attended. I even considered going back and living in California. Nevertheless, the feeling changed when I came back to the Netherlands.

The first weeks after coming back to the Netherlands I was happy and full of energy about what I had done in the US. I realized that I had really missed the Netherlands, my friends and colleagues, and my life there. I missed my own space in the Netherlands: a space in which I was not limited because I was a woman. I could live the life I wanted to. I related these feelings to my experiences in California later when I started to have nightmares. In my dreams, I was being choked in my sleep by groups of Iranians, familiar and unfamiliar faces coming closer and closer with their hands towards me. After thinking about the nightmares, I realized that in spite of the positive feelings I had about the Iranian community in California, I was also often bothered by the extent of social control there. I often heard stories about my personal life that were spread around. This showed me the power of network and rumours.

I also did not like the consumption-oriented life in California. I hated the system in which your financial credit meant everything. I often felt uncomfortable on those occasions; however, experiencing the home sweet home again, and being busy with my research covered those feelings up. Once in the Netherlands those incidents became a strong part of my life in my subconscious. When the nightmares in the Netherlands started, I not only had to deal with my feelings related to LA, but also my disillusionment with the past. In the poem I explained how I created an imaginary homeland that was warm, sunny and full of emotion. My feelings of uprootedness in the Netherlands fuelled the creation of an illusionary homeland to which I wanted to belong. Then I started to ask the question: who are you kidding? The discomfort I felt in Los Angeles with traditional ideas regarding women's roles and the gossip going around would be even worse in Iran. In Los Angeles, many of my friends spoke positively about the ability to interact in two spaces, the Iranian and the American one. Thus, in LA Iranians can distance themselves from negative traditional elements, but this distance is much more limited in Iran with an oppressive government and a strong patriarchal tradition.

Disillusioned by that unreal picture of Iran and faced with the negative aspects of California, I started analysing fieldwork material. It was a year later before I discovered that I had become much more positive about my life in the Netherlands. Based on the comparison with the US, I realized that I liked my life in the Netherlands. In the 12 years I had lived in the Netherlands, I had become Dutch. Differently Dutch, but still Dutch. By being Dutch, I do not mean having Dutch nationality (which I have), but feeling part of the Netherlands. I realized that the process of othering in 
the Netherlands had preoccupied me for a long time. I was busy seeing life in the Netherlands through a negative lens. The process of doing this research also made it possible for me to answer some questions about my life related to home, the past and the future.

The construction of my exile experience started when I felt that I was being treated as an unwanted other in the Netherlands. This made me furious, because I had worked so hard to be part of the society. It felt as if it was never enough. Then I started to distance myself from society by criticizing everything Dutch: the weather, the individualism, the coldness of people. In the last year, based on my experiences in Los Angeles, I started seeing my life in the Netherlands in a different way. I realized that I appreciate my individual space; call it individualism if you will. I have wonderful Dutch friends who are not cold and distanced. I like neither the consumption-oriented lifestyle of Iran and America, nor the exaggeration of the plain lifestyle of the Netherlands; however, if pushed, I prefer the second. The lifestyle I choose is a strange one, anyway, it will never fit entirely into any one structure. It has a hybrid character, existing in the shared space of cultural difference, which includes a variety of partial lifestyles and cultures including Iranian and Dutch.

It was then when I realized that home is where I feel at ease; where I can be the person I want to be, where I have the job I always wanted and where I have friends I like. Although I realized that now home is the Netherlands, who knows for how long? But I also realized that feeling at home is something that takes work. In the Netherlands I miss the Iranian cultural activities that I grew up with. I miss the social network I had in Iran, and that I experienced in LA. Nevertheless, my life in the Netherlands had changed me in ways that I could not ignore: I became even more aware of my individual space and what my father called 'my rebellious choices in life'. So it is possible that Iranian women with my background, my friends in LA, feel at home and belong in California. The trajectory of life of my companions and me in the Netherlands has been different: we have been spoiled by our individual space here. We are too Dutch to feel at home in either Iran or in California. What we can do is to make the Netherlands our home, as I have started to do already. The Netherlands becomes home when we start looking at its positive sides, the chances we have here, the friends we have, and the space we have created to be the person we want to be. Feeling Dutch is not about being accepted by the Dutch or becoming like the Dutch, by ignoring one's background. It is about claiming Dutchness based on being different, being Iranian. Becoming Dutch is then about being Iranian-Dutch. 


\section{CONCLUDING REMARKS}

The rich narratives of the women in this study have enabled me to rethink the notions of identity, home and belonging. When it comes to the life of migrants and refugees, home is often equated to the past. Departing from this static and fixed approach, home becomes synonymous with the country of origin where people are supposedly rooted and which they have left behind. Scholars within the field of refugee studies have also contributed to this way of approaching home by making 'the assumption that the homeland or country of origin is not only the normal but the ideal habitat for any person' (Malkki, 1995: 509). In this way, home is directly equated with the national borders of the country of origin. Malkki links this so-called sedentary bias to the claim that we live in an era of 'the national order of things' in which 'rootedness' in a culture and a geographic territory is considered to be the natural and normal feature of humanity. She disputes this kind of approach by deterritorializing the concept of home.

But if 'home' is where one feels most safe and at ease, instead of some essentialized point on the map, then it is far from clear that returning where one fled from is the same thing as 'going home'. (Malkki, 1995: 509)

To consider the country of origin automatically as 'home' also assumes 'that refugees' attachment to their homeland and their desire to return to it are "natural" givens' (Al-Rasheed, 1994: 199). Through the methodological choices in my research, such as life stories and reflective positioning and writing, I have been able to bring these theoretical insights into practice and rethink the notion of home and belonging, not just in regard to my research materials, but also in my own life as an exile. By adopting a deterritorialized notion of home, I show that the feelings of belonging and foreignness do not have to be related to a fixed place, either the homeland or the new country, but that they are related to one's position in life. The sense of belonging is not related to a soil as assumed by Hugo of St Victor: be it identifying with the 'native soil' or 'every soil in the world', or denying it all together. But it is rather to what a place can offer and how one can become part of a life in a certain place. In this way, the notion of place is not fixed but it is fluid. It is the meaning of a place that is then essential. The creation of meaning comes from memorized experiences of certain places. These memories, which change over the course of time, remain part of one's life; and it is through these memories that feelings of belonging can be created. The point here is that it is not the place as such that is important, but the matter of positionality in a place. 


\section{NOTES}

1. I use this word to refer to the Marxist ideology of the world as a homeland.

2. What many, including me, called 'the spring of freedom', was regarded by some (such as those associated with the Pahlavi regime) as a period of horror.

\section{REFERENCES}

Abu-Lughod, Lila (1991) 'Writing Against Culture', pp. 137-62 in R. Fox (ed.) Recapturing Anthropology: Working in the Present. Santa Fe, NM: School of American Research Press.

Abu-Lughod, Lila (1993) Writing Women's Worlds: Bedouin Stories. Berkeley: University of California Press.

Al-Rasheed, Madawi (1994) 'The Myth of Return: Iraqi Arab and Assyrian Refugees in London', Journal of Refugee Studies 7(2/3): 199-219.

Anderson, Kathryn and Dana C. Jack (1991) 'Learning to Listen: Interview Techniques and Analyses', pp. 11-27 in S. Berger Gluck and D. Patai (eds) Women's Words: The Feminist Practice of Oral History. London: Routledge.

Behar, Ruth (1996) The Vulnerable Observer: Anthropology That Breaks Your Heart. Boston, MA: Beacon Press.

Behar, Ruth and Deborah A. Gorden (1995) Women Writing Culture. Berkeley: University of California Press.

Berger Gluck, S. and D. Patai, eds (1991) Women's Words: The Feminist Practice of Oral History. London: Routledge.

Ghorashi, Halleh (1998) 'The Valley Ones: Conversations with Women Activists of the Iranian Revolution', Suitcase: A Journal of Transcultural Traffic 3(1\&2): 18-26.

Ghorashi, Halleh (2003a) Ways to Survive, Battles to Win: Iranian Women Exiles in the Netherlands and the United States. New York: Nova Science Publishers.

Ghorashi, Halleh (2003b) 'Multiple Identities between Continuity and Change: The Narratives of Iranian Women in Exile', Focaal: European Journal of Anthropology 42: 63-77.

Malkki, Liisa (1995) 'Refugees and Exile: From "Refugee Studies" to the National Order of Things', Annual Review of Anthropology 24: 495-523.

Said, Edward W. (1994) Culture and Imperialism. London: Vintage.

Halleh Ghorashi is Assistant Professor of Organizational Anthropology in the Department of Culture, Organization, and Management at the Vrije Universiteit in Amsterdam. She was born in Iran and came to the Netherlands in 1988. In 1994, she completed her MA degree in anthropology at the Vrije Universiteit. She received her PhD in 2001 from the University of Nijmegen. She is the author of Ways to Survive, Battles to Win: Iranian Women Exiles in the Netherlands and the US (New York: Nova Science Publishers, 2003) and several articles on questions of identity, diaspora and the Iranian women's movement. Address: Department of Culture, Organization and Management, De Vrije Universiteit Amsterdam, De Boelelaan 1081c, 1081 HV Amsterdam, The Netherlands. [email: h.ghorashi@ fsw.vu.nl] 